\title{
1914 and the Archaeology of Modern Industrialised War
}

1914 et l'archéologie de la guerre industrialisée moderne

\section{Neil Faulkner}

\section{(2) OpenEdition}

1 Journals

\section{Electronic version}

URL: http://journals.openedition.org/rfcb/290

DOI: $10.4000 / \mathrm{rfcb} .290$

ISSN: 2429-4373

\section{Publisher}

CRECIB - Centre de recherche et d'études en civilisation britannique

\section{Printed version}

Date of publication: 15 January 2015

ISSN: 0248-9015

\section{Electronic reference}

Neil Faulkner, " 1914 and the Archaeology of Modern Industrialised War », Revue Française de Civilisation Britannique [Online], XX-1 | 2015, Online since 01 May 2015, connection on 04 May 2019. URL : http://journals.openedition.org/rfcb/290 ; DOI : 10.4000/rfcb.290

This text was automatically generated on 4 May 2019.

\section{(c)}

Revue française de civilisation britannique est mis à disposition selon les termes de la licence Creative Commons Attribution - Pas d'Utilisation Commerciale - Pas de Modification 4.0 International. 


\title{
1914 and the Archaeology of Modern Industrialised War
}

\author{
1914 et l'archéologie de la guerre industrialisée moderne
}

\author{
Neil Faulkner
}

1 Tory Prime Minister David Cameron is spending £55 million on commemorating the centenary of the First World War. Speaking at a press conference at the Imperial War Museum in October 2012, Cameron made the announcement in front of Paul Nash's painting The Menin Road. The title is ironic. There is no road in the picture. It has been destroyed by shell-fire. Instead, stretching to the horizon is a landscape of mud, tree stumps, ruined buildings, barbed wire, water-filled craters, and the concrete blocks and corrugated iron of shattered bunkers. Shells explode in the distance. Four soldiers pick their way through the mire.

2 The Menin Road depicts the battlefield of Passchendaele in Flanders. It was, wrote war poet Wilfred Owen, 'a sad land, weak with sweats of death, grey, cratered like the moon with hollow woe, and pitted with great pocks and scabs of plagues'. For in this place, during three months of drenching rain in 1917, two million men fought each other for possession of patches of slime and rubble. Nash's painting depicts a new reality: modern industrialised warfare. Some argue that an earlier war - usually it is the American Civil War - was 'the first industrialised war'. This is not so. The American Civil War was semiindustrialised. There were steamships, railways, and telegraphs. But there were also muzzle-loading guns, shoulder-to-shoulder firing lines, and men charging across the battlefield with flags and drums. The technology was somewhere between the Napoleonic Wars and the First World War.

3 That is why the First World War began as it did: with an outdated military paradigm, because theory had not yet caught up with reality. The French were perhaps the most backward; Napoleonic fantasies were a substitute for industrial and demographic weakness. Lines of French infantry in blue coats and red trousers charged machine-guns and modern artillery. The French lost a quarter of their men in a single month. 

extended over dozens of square kilometres. The terrain was reduced to a wasteland like that depicted in The Menin Road. For most of the time no-one could be seen. Troops remained in underground complexes of trenches and tunnels. When attacking, they crept forward in small groups, rushing from shell-hole to shell-hole. Casualties reached a million in battles like the Somme and Verdun. Yet the war went on, and the demand was always for more men, more guns, more shells. Industrial output was decisive, millions were mobilised in war industries, and 'the home front' became a target of bombing and blockade.

What was happening was outside all previous human experience, and the effect of the war was to tear societies apart and destabilise the entire social order. This is the crucial insight of Gabriel Kolko in his seminal study, A Century of War (1994), in which he grasps the way in which industrial power is transformed into means of destruction of such force that uncontrollable processes of societal collapse are unleashed.

This is the subject-matter of Modern Conflict Archaeology.

\section{A radical new academic sub-discipline}

7 Nick Saunders, formerly of University College London, now at Bristol University, has pioneered the development of Modern Conflict Archaeology as a new academic subdiscipline over the last 15 years or so. A mix of anthropologist and archaeologist, his first major published study in the field was Trench Art: materialities and memories of war (2003), a study of art objects created in the context of war, often using battlefield detritus like shell cases.

Before Saunders' work, no-one had taken this category of material culture seriously. Neither military historians nor art historians were interested. Many colleagues expressed surprise and doubt when Saunders declared his research interest. What he demonstrated is that each of these objects 'contains' a story of human experience in war, often visceral experience involving the most intense emotion, the object becoming the physical embodiment of the memory. It might be the post-war widow, visiting the battlefield, purchasing a souvenir, and then displaying on the mantelpiece an art nouveaux-decorated shell case that could have contained the very explosive which destroyed her husband.

More recently, Saunders has published Killing Time: archaeology and the First World War (2007), a comprehensive introduction to the sub-discipline, covering the full range of archaeological approaches to the landscapes and the material culture of the war. This is a world away from the crude 'buttons and bullets' surveys carried out by sundry 'battlefield archaeologists'. It is about investigating the entire human experience of modern industrialised warfare through the lens provided by material as opposed to text. It is about the insights to be gained from the transformation of landscapes and the creation, use, and loss of objects in the context of war.

10 Saunders' latest book, The Poppy: a cultural history from Ancient Egypt to Flanders Fields to Afghanistan (2013) is a case-study in this approach. It is a tour de force, a systematic analysis that extracts every ounce of meaning from the paper-and-plastic imitation poppies worn by millions every November. 'Separate, but forever intertwined,' he writes, 'the corn and opium poppies have generated more wealth, misery, hope, and death than 
any flower in human history, and together they have created the Remembrance Poppy, surely one of the most ambiguous and enduring symbols of our humanity.'

11 A series of conferences run by Saunders and Paul Cornish at the Imperial War Museum (with associated volumes of published papers) has provided an opportunity for archaeologists, anthropologists, military historians, museum curators, cultural historians, and even radical artists to exchange ideas. The result is a multi-disciplinary mix which lifts Modern Conflict Archaeology clear of the parochialism of most subject specialists. It is intolerant of a narrow focus on battle plans, object typologies, or war poems. It demands their contextualisation as a contribution to a comprehensive view of the human experience of modern industrialised war. 'Running through all these varied aspects like an electric current,' says Saunders of his trench-art research, 'were the lives of real people. They had names, signatures, and faces, and their letters, photographs, and objects seemed to me to announce a new kind of archaeology - that of the recent historical past in time of conflict.'

The new sub-discipline has subsumed within itself part of an older established tradition of 'battlefield archaeology'. Much of this otherwise remains unreconstructed. Some of it is not 'archaeology' at all, but straightforward looting for personal gain. Some of it, performed for the TV cameras, is only marginally better, being almost wholly devoid of academic purpose. Some is technically rigorous in an archaeological sense, with, for example, meticulous plotting of metal-detected debris, but remains theoretically disengaged and therefore rather pointless: a bag of bullets from a muddy field tells us what exactly? The pioneering study of this kind is that by Doug Scott and colleagues of the Battle of the Little Bighorn (1989), which really did provide the evidence for reconstructing more completely than ever before what actually happened on the battlefield. The truth is that no field project since has had such an impact on conventional accounts. Tweaking the military history should not be the primary aim.

It is when battlefield archaeology dissolves into Modern Conflict Archaeology that something of real academic value emerges. The survey, excavation, and metal-detecting of the battlefield then becomes part of a much wider endeavour to grasp the scale, multidimensionality, and emotionally super-charged phenomenon of modern industrialised warfare.

\section{What is modern industrialised warfare?}

The sub-discipline of Modern Conflict Archaeology is still in its infancy, groping towards the conceptual tools it requires to make full sense of an accumulating corpus of data. At present it comprises a rather disparate cross-disciplinary collection of case-studies without any overarching framework. Part of the problem is the corrosive effect of postmodernism on fragmenting knowledge, such that each contribution is left floating in a void, and conclusions tend towards the banal.

A current fashion, for example, is work on 'the senses', an attempt to reconstruct the allround sensory experience of modern industrialised war. Many fascinating and valuable case-studies have emerged. But this is not enough, for, to describe the feeling of claustrophobia inside a U-boat, the nausea in a Zeppelin, or the smell of rotting bodies, gas, and liquid mud in a trench is just that: description. We need to be able to explain why this is happening - why, if you will, the world went mad between 1914 and 1918, and 
condemned millions of men to violent death and mutilation in industrialised killingfields.

Building-blocks of understanding can be derived from a combination of the theories of Engels, Marx, Lenin, and Freud. In The Origins of the Family, Private Property, and the State (1884), Engels argued that the three institutions referred to in his title arose in tandem, each of them essential features of emergent class society. The patriarchal family was linked with the development of private property, and this in turn created the social tensions which necessitated the state, defined as 'armed bodies of men'. He explained:

The second distinguishing feature is the establishment of a public power which no longer directly coincides with the population organising itself as an armed force. This special public power is necessary because a self-acting armed organisation of the population has become impossible since the split into classes... This public power exists in every state ...

The state, in other words, is controlled by the ruling class, and it is used by them to protect their property and wealth. It therefore faces in two directions: downwards as an instrument for suppressing popular revolt; and outwards as an instrument of both defence and offence against rival ruling classes. We can therefore add a fourth member to Engel's triad: war. The division of the world among rival ruling classes, the existence of surplus wealth which might be seized by force, and the emergence of the 'armed bodies of men' constituting the state, mean that war - mass organised violence - also arises with the development of class society.

For 5,000 years, war was endemic, but its impact was usually limited, mainly because traditional agricultural societies could not generate the surpluses necessary to sustain large armies on a permanent war-footing, nor the technology necessary to turn killing into a process of mass destruction. The Industrial Revolution transformed the killingpower of the world's rulers. The Prussian Army at Waterloo in 1815 had numbered 60,000; the Prussian Army at Sedan in 1870, 200,000. But the German Army on the Western Front in 1914, which, in a sense, was a single vast battlefield extending from Switzerland to The Channel, numbered 1.5 million. Mass production provided the guns, munitions, and supplies to keep such huge masses fighting. The British had 156 guns at Waterloo, and they fired a few thousand rounds in total; at the Somme in 1916 they had 1,400 guns, all of them far more powerful, and they fired nearly two million shells in the first few days.

Modern industrialised war is the supreme expression of the 'reification' analysed by Marx, where human economic activities and social relationships are transformed into impersonal alien forces beyond rational control. The First World War brought carnage, destruction, and waste without precedent. Industrial society's capacity to satisfy human need through mass production had turned into its opposite: a Frankenstein's monster of industrialised slaughter. The alienation of soldiers in the trenches was that of human beings about to be torn apart by the products of human labour.

Lenin's Imperialism: the highest stage of capitalism (1916) provided a summary analysis of the economic, social, and political forces that had propelled the world into the abyss. He described the growing domination of the global economy by giant banks and industrial corporations, their partial fusion with one another, their organisation into cartels, and their intimate ties with the state, such that the world had divided into national-capitalist blocs competing for empire and profit.

21 Imperialism, driven by the growing 'centralisation and concentration of capital', has continued to evolve, but its essential character remains: it is a dynamic and complex 
system of global competition between banks, corporations, and states, with war and preparation for war an inherent characteristic. The basic picture is sometimes obscured by the existence of regional powers and local militias, but often these turn out to be the client regimes and proxy armies of the great powers, and even where they are not, few survive for long without external aid. It is imperialism that frames the global system and fuels its wars.

Finally there is Freud. What Marx accomplished for human society - its scientific analysis - Freud accomplished for the human mind. As with Marxism, much of the detail in psychoanalysis can be disputed, but not the value of the method and the conceptual foundations. Freud thinks in terms of a 'psychic economy', of surges of 'libido' - the life force - that have to be managed, and of dysfunctions arising from the clash between 'the pleasure principle' (the yearning of the organism for sensual satisfaction) and 'the reality principle' (the constraints imposed by social life). The impulses emanating from the unconscious Id are repressed by the conscious Ego as it adjusts behaviour to the norms of everyday life. But what if repression is excessive or inappropriate? What forces might accumulate in the depths of an anxious psyche, and what murderous forms might they sometimes take when unleashed?

The First World War fused the technology of the $20^{\text {th }}$ century with the myths of the $10^{\text {th }}$. Nationalism was tribalism writ large. The cult of the ruler - King, Kaiser, Tsar, Sultan - or flag - Union Jack, Tricolour, Imperial Eagle, Star and Crescent - was father-worship and totemism. The hocus-pocus of imperial ideology is transparent nonsense, yet millions were duped and found deep inside themselves the reserves of hate and aggression to become murderous demons.

These theories - about the state, the industrialisation of war, reification and alienation, imperialism, 'the return of the repressed' and 'primal man' - provide the conceptual tools we need to frame the rich datasets being accumulated by the developing sub-discipline of Modern Conflict Archaeology.

\section{The revisionist challenge}

Damaged by Iraq, ground down in Afghanistan, defeated over Syria, Britain's rulers are in recoil from the War on Terror imperialism of the last 12 years. Their ability to launch new military adventures is now hamstrung by an 'Iraq Syndrome' - a compound of intractable opposition on the ground, of conflicts spiralling out of control, of rival imperial powers matching them move for move, and of domestic populations now firmly anti-war

In October 2001, almost $90 \%$ of Britons polled approved of Blair's handling of the Afghan crisis, and three-quarters supported the bombing campaign then under way. By 2009 only half of those polled supported the Afghan War, and by 2012 it was down to a quarter. In a recent poll (December 2013), two-thirds of Americans said that the Afghan War was not worth fighting; even one in three of US combat veterans were of this opinion. This dramatic swing of opinion - in defiance of the entire political establishment and their media echo-chambers - is in part a response to the obvious carnage, destruction, waste, and failure of the War on Terror. But opinion is not formed in an ideological vacuum: it is also a testimony to the size and impact of the anti-war movement. battleground. The year has begun with a very public row pitting Tory Education Minister 
Michael Gove against his Labour shadow Tristram Hunt, with prominent right-wing historians like Max Hastings, author of a major revisionist study, Catastrophe: Europe goes to war 1914 (2013), yapping around them.

Gove claims that historians have 'demonstrated that those who fought were not dupes but conscious believers in King and Country, committed to defending the Western liberal order'. Many British men did indeed volunteer to fight for 'King and Country'. Whatever that meant to them, it clearly had nothing to do with their real interests. Just as it was not in the interests of German men to fight for the Kaiser, Russian men to fight for the Tsar, or Turkish men to fight for the Sultan. Cambridge historian Richard Evans - one of the 'left-wing academics' condemned by Gove - is therefore absolutely right to argue: 'the men who enlisted in 1914 may have thought they were fighting for civilisation, for a better world, a war to end all wars, a war to defend freedom: they were wrong'.

The job of historians is to cut through the lies. Millions were indeed duped by the ideologies of their rulers in 1914: nationalism, imperialism, military glory, allegiance to monarch and flag, and all the rest. By 1918 millions of them knew better. Soldiers were streaming out of the trenches and threatening to gun down officers who tried to stop them; and workers were on the streets at home toppling warmongers from their thrones and settling accounts with the war-profiteers who employed them.

Michael Gove deplores 'an unhappy compulsion on the part of some to denigrate virtues such as patriotism, honour, and courage'. This is the garbage that killed 15 million between 1914 and 1918. When Gove talks about 'patriotism', he means nationalism, imperialism, and militarism. When he talks about 'honour', he is not thinking of the 'honour' of the Suffragette, the striking miner, or the Irish nationalist. And when he talks about 'courage', he is not referring to the courage of the pacifist, the mutineer, or the revolutionary.

31 Gove then proclaims that 'Britain's role in the world has been marked by nobility and courage', and that Britain has a 'special tradition of liberty'. Unlike Germany: 'the ruthless Social Darwinism of the German elites, the pitiless approach they took to occupation, their aggressively expansionist war aims, and their scorn for international order, all made resistance more justified.' Here is the heart of the revisionist argument: the First World War was a struggle between the good empires (Britain and France; presumably not Russia) and the bad empire (Germany).

32 Then, having won, the British helped themselves to Palestine, Jordan, Iraq, Namibia, and Tanzania, the French to Syria, Lebanon, Togo, and Cameroun. They also planned to divide up Turkish-speaking Anatolia between themselves and the Italians and the Greeks; a project frustrated only by Turkish nationalist resistance.

33 After the war against Prussian 'militarism', it turned out there was Anglo-French militarism instead, as protestors demanding independence were gunned down - by the French in Syria, for example - or bombed from the air - by the British in Iraq. It is the outcome that gives the lie to revisionist arguments about the First World War. It was a war for empire and profit in which the many were sacrificed for the wealth and power of the few, and in which the rulers of Britain and France demonstrated that they represented not 'nobility' and 'liberty', but a world of exploitation, oppression, and violence. Winning this argument again - as, in a sense, the Left had won it by 1918, when a wave of revolution brought the war to an end - has become an important component of the wider argument against imperialism and war in the present. 


\section{AUTHOR}

NEIL FAULKNER

University of Bristol 